\title{
Managerial change and strategic change: The temporal sequence
}

\author{
Marta Domínguez-CC and Carmen Barroso-Castro
}

\begin{abstract}
The relationship between managerial change and strategic change is a complex issue that challenges our understanding of how firms react to their business environment. In this study, we analyse the influence of the management team and more specifically their knowledge and capabilities in the process of strategic change. To do so, we delve deeper into the relationship between managerial change and strategic change by identifying the sequence of these changes. Using qualitative methodology, we analyse 10 companies listed on the Spanish Stock Exchange over an extensive period to formulate our propositions. Our analysis shows that managerial change precedes strategic change. Top management team reorganization, even without Chief Executive Officer succession, was a sufficient condition for strategic change to take place. Moreover, we identified key modifications that took place whenever strategic change occurred. Our results provide meaningful insights into the processes of strategic change within firms that broaden our theoretical knowledge in this area.
\end{abstract}

Keywords: CEO succession, TMT, managerial change, reorganization, strategic change

Received 21 March 2014. Accepted 17 October 2016

$\mathrm{O}$ rganizations in the 21 st century are characterized by ever-increasing global competition, greater customer expectations and constant change. In this situation, the most risky strategy is inaction (Wind \& Main, 1999; Beer \& Nohria, 2000; Farjoun, 2007) or predictability (Rindova, Ferrier, \& Wiltbank, 2010). Thus, the strategic fit is still central to strategic management nowadays. Understanding this process can facilitate prompt decision making at a time when speed has become a competitive weapon and it may also facilitate the strategic fit that all organizations desire (Rajagopalan \& Spreitzer, 1997).

According to the resources- and capability-based theory, strategic change can be understood as a dynamic process that takes place in the firm, in response to managerial interpretations of external or internal events (Adner \& Helfat, 2003; Gedajlovic, Lubatkin, \& Schulze, 2004; Clark \& Soulsby, 2007; Boyne \& Meier, 2009). According to this perspective, the capability of a firm to respond to its environment is linked to the aptitude, experience and competence of its top managers (Adner \& Helfat, 2003; Gedajlovic, Lubatkin, \& Schulze, 2004). Some researchers have pointed out that top managers become blind to the need for change (Miller \& Shamsie, 2001), because they are committed to current strategies (Miller, 1993). Therefore, senior managerial turnover is the primary agency by which strategic change can occur (Barker, Patterson, \& Mueller, 2001; Bigley \& Wiersema, 2002; Boyne \& Meier, 2009). Nevertheless, greater attention has to be

Departamento de Administración de Empresas y Marketing, University of Seville, Seville, Spain

Corresponding author: martad@us.es 
paid to the role of managers in strategic change (Adner \& Helfat, 2003), because there is still considerable ambiguity over what top managers actually do in the strategic planning process (Jarzabkowski, 2008). In this sense, our investigation sets out the following research question: Is it necessary to incorporate new knowledge and capabilities in the top management team (TMT) to achieve strategic change? A response to this question implies: (i) delving deeper into the sequence between managerial change and strategic change; and, (ii) taking a closer look at the concept of strategic change, considering it as a complex construct with multiple interactions between its components. Both the sequence and the content of these changes as a process have been overlooked by researchers (Van de Ven \& Poole, 2005).

Establishing the temporal sequence of change is per se one of the most important research questions in the field of management, because its implementation may speed up in increasingly dynamic and turbulent environments (Rajagopalan \& Spreitzer, 1997). We first need to establish the sequences between both processes (Van de Ven \& Poole, 1995), in order to establish a causal relationship between managerial change and strategic change. Prior research in this field has led to inconclusive results. Although some authors have contended that managerial change precedes strategic change (Gordon, Steward, Sweo, \& Luker, 2000; Barker, Patterson, \& Mueller, 2001; Bigley \& Wiersema, 2002; Datta, Rajagopolan, \& Zhang, 2003; Boyne \& Meier, 2009), others have placed strategic change before managerial change (Wiersema \& Bantel, 1993; Jarzabkowski, 2003; Zhang, 2006). The inconsistency of the results may perhaps be explained by the different ways of measuring strategic change. Most empirical studies on corporate governance and strategic change have adopted a narrower approach in their definition of strategic change (Brunninge, Nordqvist, \& Wiklund, 2007). According to Van de Ven and Poole (2005), this work considers the concept of strategic change as a process that describes, (1) the temporal order and sequence of events (narrative process); and, (2) the analysis of differences in the different dimensions of strategic change over time: strategy, structure, power and control system.

Our results show that the reorganization of roles between the members of the team, a previously unused typology of change in the TMT, permits the renewal of the capabilities and knowledge of the top managers. The majority of previous studies on the literature have centred on the incorporation of new capabilities and knowledge through the incorporation of new members in TMT, excluding the perspectives considered in this work. Our investigation shows how the assignment of new responsibilities to current top managers increases their awareness of change in their environment, because they analyse it from a new approach, in a new role. In this way, renewed use of the capabilities and the knowledge of the TMT provoke strategic change, without any need to change the composition of the TMT.

Furthermore, our research has identified key orientations in the development of strategy and structure, which means that we may improve our knowledge of the construct of strategic change. The proposed analysis has allowed the identification of key orientations in the strategy (linked to growth and innovation) and the structure of the firm (visible in its organizational chart and business unit reorganization) that are always present when strategic change takes place.

Finally, following the suggestions of various authors (Pettigrew, 1990, 1997; Van de Ven \& Huber, 1990; Van de Ven, 1992; Van de Ven \& Poole, 1995, 2005; Pettigrew, Woodman, \& Cameron, 2001), a longitudinal qualitative analysis was performed, to take into consideration both the dynamic character of the firm and the specific nature of the change itself. Qualitative information enables propositions and hypotheses to be put forward. This information will then form the basis of future research (Noda \& Bower, 1996).

The remainder of this paper is structured into four sections. The next section presents a review of the literature on strategic change and managerial succession. The following section describes the methodology employed in the study, followed by a presentation of the findings. The paper concludes with a summary of the conclusions and their implications, including suggestions for future avenues of research. 


\section{THEORETICAL FRAMEWORK}

\section{Direction of change}

The resource- and capability-based theory of the firm supports the view that the capability of a company to respond to its environment is linked to the aptitude, experience and competence of its TMT (Dutton \& Duncan, 1987; Adner \& Helfat, 2003; Gedajlovic, Lubatkin, \& Schulze, 2004), which in turn determine priorities regarding its resources and capabilities (Mosakowski, 1998). Since this perspective, TMT change is considered as an adaptive mechanism to assure strategic change (Wiersema \& Bantel, 1993; Hayward \& Shimizu, 2006; Decker \& Mellewigt, 2012). Taking these arguments into account, our work begins with the idea that managerial change precedes strategic change. The literature points out that managers possess different qualities and quantities of generic, industry-specific, firm-specific (Castanias \& Helfat, 1991, 2001) and related industry skills (Bailey \& Helfat, 2003) that are at the same time valuable, rare, inimitable, nonsubstitutable and difficult to transfer. In the case of managerial change, only some of these skills are transferable. So, firm-specific and industry-specific skills held by managers are difficult to exploit, if the top managers change their firm or industry. On the contrary, if top managers change positions within the firm, they can exploit all of their skills. Nevertheless, researchers indicate that new top managers who have arrived at their posts through internal promotion, from within the firm, are accustomed to the way of doing things in the firm, and are less likely to initiate strategic change (Hambrick, Geletkanycz, \& Fredrickson, 1993). In contrast, an employee from another firm who accesses a top manager post provides a fresh perspective that favours strategic change (Bailey \& Helfat, 2003), although not all of their capabilities may be exploited, especially firm-specific skills (Harris \& Helfat, 1997). Our research question takes this idea further. In particular, we question whether changes in the composition of the TMT are necessary to achieve strategic change.

Changes in senior management enrich the number of perspectives and increase the resource base, which gives the TMT the means to recognize the need for strategic change (Castro, de la Concha, Gravel, \& Periñan, 2009). New capabilities usually require knowledge that is likely to differ from the current knowledge base of the company (Zahra \& Filatotchev, 2004). In short, the arguments of the resource- and capability-based theory of the firm point to the importance of renewal of the resources and capabilities of the TMT, through changes in the composition of the TMT. Hence, the strong influence of top managers, from this perspective, on the response of the firm to external changes (Virany, Tushman, \& Romanelli, 1992; Tushman \& Rosenkopf, 1996; Rosenbloom, 2000). Accordingly, some authors point out that Chief Executive Office (CEO) succession (Decker \& Mellewigt, 2012) and TMT turnover (Tushman \& Rosenkopf, 1996; Barker, Patterson, \& Mueller, 2001; Bigley \& Wiersema, 2002; Boyne \& Meier, 2009) are key factors to overcome organizational inertia and facilitate strategic change. In practical terms, any change in the TMT provides an opportunity to evaluate the role played by the senior executives in formulating and executing company strategy. If changes in top management precede strategic change, it is logical to suppose that a causal relation may exist between top managers and strategic change.

\section{TMT changes and the components of strategic change}

Strategic change involves simultaneous and discontinuous shifts throughout the organization in strategy, power, structure and control (Virany, Tushman, \& Romanelli, 1992). But, the majority of studies about corporate governance and strategic change have focussed on only one component of change - such as strategy (Miller, 1993; Boeker, 1997; Greve \& Mitsuhashi, 2007; Zhang \& Rajagopalan, 2010), structure (Balogun \& Johnson, 2004), power distribution (Weisbach, 1988; Miller, 1993) and control systems (Simons, 1994). Such a narrow definition of strategic change 
prevents the complexity of interactions between the different organizational and environmental variables from being captured (Rajagopalan \& Spreitzer, 1997). Some authors have also contended that 'strategic change' implies 'radical modifications' that take place within a short space of time - perhaps 2 years (Tushman \& Romanelli, 1985; Romanelli \& Tushman, 1994; Tushman \& Rosenkopf, 1996; Gordon et al., 2000). However, more recent studies have shown that the critical factor is the magnitude of change, rather than the time taken to implement it (Amis, Slack, \& Hinnings, 2004).

In the literature, several studies have linked managerial succession to changes in one or more of the above-listed variables in the definition of strategic change - that is, strategy, structure, power distribution and control systems (Table 1). CEO succession (Miller, 1993; Simons, 1994; Pitcher, Chreim, \& Kisfalvi, 2000) and TMT changes have a positive influence on strategy formulation (Boeker, 1997; Barker, Patterson, \& Mueller, 2001); on structure (Lant, Milliken, \& Batra, 1992; Barker, Patterson, \& Mueller, 2001); on power distribution (Weisbach, 1988; Miller, 1993; Romanelli \& Tushman, 1994); and on control system (Simons, 1994; Barker, Patterson, \& Mueller, 2001). However, their results have been inconsistent. Furthermore, some have referred to changes in 'corporate strategy' when discussing such matters (Boeker, 1997), while others have considered changes to the level of 'business tactics' (Barker, Patterson, \& Mueller, 2001).

It is apparent from this brief review of previous studies (see Table 1) that empirical evidence exists to show that CEO succession, in particular, and, to a lesser extent, TMT turnover both affect a range of variables that can be considered components of strategic change. However, considerable ambiguity persists over the actual activities of top managers in the process of strategic change (Jarzabkowski, 2008). Besides, most of these studies have focussed on only one of these components of change, and especially on strategy. This paper includes all the components of strategic change and analyses the essential modifications that have to be present, so that we may consider change as strategic change.

\section{METHODOLOGY}

A response to our research question implies: (i) in the first place, an examination of the relation between managerial change and strategic change in greater depth, by analysing the sequence between these processes; and, (ii) in second place, it implies looking at both the concept and the content of strategic change in greater depth.

Certain authors have analysed the most suitable research methods for the study of company change. These methods take into consideration both the dynamic character of the firm and the nature of change itself. Prominent among these methods are those proposed by Pettigrew (1990, 1997), Van de Ven and Huber (1990), Van de Ven (1992), Van de Ven and Poole (1995; 2005) and Fox-Wolfgramm (1997). Two definitions of change are often used in organizational studies: (i) an observed difference over time in an organizational entity on selected dimensions; and, (ii) a narrative describing a sequence of events on how development and change unfold (Van de Ven \& Poole, 2005). The second approach is often associated with a process theory explanation of the temporal order and sequence, in which events occur based on a story or historical narrative that involve change (Pettigrew, 1990, 1997; Pentland, 1999; Poole, Van de Ven, Dooley, \& Holmes, 2000). From this point of view, events represent changes in the variables and these changes constitute stages in the process within an input-process-output model. Thus, as a process unfolds, its sequence of events, inherent causes and consequences can be observed, and the proverbial 'black box' is opened to establish the antecedents and the results of the changes that have been observed (Van de Ven \& Huber, 1990). This analysis calls for longitudinal research in which files, documents and reports illustrate the company's objectives, as well as the visible results of the changes that have been implemented in them. 
Table 1. Literature reView

\begin{tabular}{|c|c|c|}
\hline Authors & Sample & Principal contributions \\
\hline Barker et al. (2001) & $\begin{array}{l}\text { Declining firms attempting } \\
\text { turnarounds }\end{array}$ & $\begin{array}{l}\text { Extent of TMT replacement positively influences both business-level strategic change and change in } \\
\text { structure and control but had no relationship with domain change activity. } \\
\text { There may be reciprocal causality between the extent of TMT replacement and business-level } \\
\text { strategy change }\end{array}$ \\
\hline $\begin{array}{l}\text { Barker and Duhaime } \\
\text { (1997) }\end{array}$ & Successful firm turnarounds & Greater level of strategic change(change in strategy) if CEO is replaced \\
\hline Boeker (1997) & $\begin{array}{l}67 \text { firms in the semiconductor } \\
\text { industry }\end{array}$ & $\begin{array}{l}\text { TMT turnover from other semiconductor firms is positively related to strategic change (new product - } \\
\text { market) }\end{array}$ \\
\hline Gordon et al. (2000) & $\begin{array}{l}\text { Furniture and computer software } \\
\text { firms }\end{array}$ & $\begin{array}{l}\text { CEO changes positively influence with strategic change } \\
\text { TMT turnover decreased likelihood of strategic change } \\
\text { TMT heterogeneity is not related to strategic change }\end{array}$ \\
\hline $\begin{array}{l}\text { Greve and Mitsuhashi } \\
\text { (2007) }\end{array}$ & & $\begin{array}{l}\text { Newly hired CEO is not related to strategic change } \\
\% \text { TMT entries are negatively related to strategic change } \\
\% \text { TMT exits are not related to strategic change }\end{array}$ \\
\hline $\begin{array}{l}\text { Lant, Milliken, and } \\
\text { Batra (1992) }\end{array}$ & $\begin{array}{l}\text { Furniture and computer software } \\
\text { firms }\end{array}$ & $\begin{array}{l}\text { CEO changes positively influence with strategic change } \\
\text { TMT turnover is not related to strategic change } \\
\text { TMT heterogeneity is positively related to strategic change }\end{array}$ \\
\hline Miller (1993) & $\begin{array}{l}36 \text { medium- or large-sized firms } \\
\text { from mature industries }\end{array}$ & CEO succession is positively related to changes in organizational dimensions \\
\hline $\begin{array}{l}\text { Pitcher, Chreim, and } \\
\text { Kisfalvi (2000) }\end{array}$ & Case study & $\begin{array}{l}\text { All CEO succession were followed by strategic and structural change regardless of CEO origin, prior } \\
\text { performance, etc. }\end{array}$ \\
\hline Simons (1994) & 10 newly appointed CEO & CEOs use control system to promote strategic change \\
\hline $\begin{array}{l}\text { Romanelli and } \\
\text { Tushman (1994) }\end{array}$ & Firms of cement industry & $\begin{array}{l}\text { CEO change have a relative impact on the firm } \\
\text { Discrimination between the effects of TMT turnover and CEO change } \\
\text { The combination of CEO change and TMT turnover depends of the turbulence of environment }\end{array}$ \\
\hline $\begin{array}{l}\text { Virany, Tushman, \& } \\
\text { Romanelli (1992) }\end{array}$ & 38 minicomputer firms & $\begin{array}{l}\text { High performing firms initiate reorientation and TMT turnover without CEO succession } \\
\text { Internally promoted CEO initiates widespread changes in TMT and throughout the firm improving } \\
\text { firm performance }\end{array}$ \\
\hline $\begin{array}{l}\text { Wiersema and Bantel } \\
\text { (1992) }\end{array}$ & $\begin{array}{l}87 \text { of the } 500 \text { largest } \\
\text { manufacturing firms }\end{array}$ & $\begin{array}{l}\text { Average tenure of TMT is positively related to strategic change } \\
\text { Tenure heterogeneity of TMT is not related to strategic change }\end{array}$ \\
\hline $\begin{array}{l}\text { Zhang and } \\
\quad \text { Rajagopalan (2010) }\end{array}$ & $\begin{array}{l}176 \text { publicly traded manufacturing } \\
\text { firms }\end{array}$ & The origin of the CEOs affects their ability to formulate and to implement strategic changes \\
\hline
\end{tabular}

Note. $\mathrm{CEO}=$ Chief Executive Officer; TMT = top management team. 


\section{Sample and data collection}

The initial information was constituted by all the firms listed on the Madrid Stock Exchange (Spain). We selected those firms because they provide greater access to information on the composition of their governance organs. Moreover, the listed firms are much more visible than other firms and therefore, any relevant strategy-related event would be reported in the press. Likewise, the availability of information in annual reports, relevant acts, etc., has helped us to contrast and to verify the data extracted from the press (Churchill, 1999).

The period of study ran from 1993 up until 2000, a period chosen for two fundamental reasons. In the first place, an important change occurred over this period in the business setting, driven by globalization and the technological revolution, which prompted many large Spanish firms to introduce strategic change (Sánchez, Galán, \& Suárez, 2006). On the other hand, unlike in the earlier decade, the number of mergers over the aforementioned period was not excessive, which would otherwise have introduced bias into our investigation, when including changes in senior management due to mergers. We therefore consider that the period is suitable to pursue the objective of our study.

We began by analysing the management changes that the firms listed on the Bolsa de Madrid (Spanish Stock Exchange) experienced during the 8-year period under study. The data on these changes were collected by comparing the lists of managers in the firms' annual reports on a year-by-year basis. Three types of managerial change were identified (Tushman \& Rosenkopt, 1996; Gordon et al., 2000; Barker, Patterson, \& Mueller, 2001): succession: when the CEO changed or a CEO post appeared; turnover: when there were changes in other personnel of the TMT; and reorganization: when posts or people in positions of responsibility within the team appeared or disappeared. Turnover, which implies changing a person in a particular post, was initially considered more important for the induction of strategic change, from the point of view of the resource- and capability-based theory, because it implies a change in the set of resources and capabilities of the TMT. Therefore, reorganization was considered a minor change, because it may imply a redistribution of duties among the same employees, rather than a change in the members of the management team. Thus, the set of resources and capabilities of the TMT are maintained, although their use and application can change with reorganization. Hence, we only classified companies by CEO succession and turnover. Using qualitative data methods, we selected those companies that we expected to yield the most explanatory results. This list included those with the least typical data (Yin, 1993; Silverman, 2005; Eisenhardt \& Graebner, 2007; Siggelkow, 2007), such as CEO succession without TMT turnover and TMT turnover without CEO succession, which were relatively less frequent and would not fit in with the relations that we wished to establish (Gibbert \& Ruigrok, 2010), in order to ensure internal validity. Our objective was to provide a wide range of examples of succession and TMT turnover. The two extremes of high-turnover companies and firms with no change in their TMT were included to further our understanding of the relations under analysis (Eisenhardt \& Graebner, 2007). Finally, a sample was constituted of 10 Spanish companies on the basis of qualitative information over the 8-year period of the study.

Of the 10 selected firms, four - the first to the fourth in Table 2 - had undergone CEO succession and TMT turnover; two firms - the fifth and the sixth - had undergone CEO succession but no TMT turnover; two firms - the seventh and the eighth firms - had experienced TMT turnover, but no CEO succession; and two companies - the ninth and the tenth firms - had neither experienced CEO succession nor significant turnover in the TMT throughout the entire period under study. Four examples were placed in CEO succession and TMT changes to diversify the range in this section. Eisenhardt (1989) suggested that four to ten case studies may provide a sound basis for analytical generalization. Besides, different subperiods of change for each company could be identified over the extensive time span of our study. This breakdown into subperiods increased the number of 
TABle 2. SAMPLE CHARActeristics

\begin{tabular}{|c|c|c|c|c|}
\hline Managerial change & Company & Environment & Sector & Fundamental characteristics \\
\hline \multirow[t]{4}{*}{$\begin{array}{l}\text { Succession - TMT } \\
\text { turnover }\end{array}$} & Firm 1 & Stable & Hotels, restaurants and cafés & $\begin{array}{l}\text { Very fast expansion and growth } \\
\text { Multiplied } 20 \text {-fold its number of outlets in the period }\end{array}$ \\
\hline & Firm 2 & Incertainty & $\begin{array}{l}\text { Production and assembly of } \\
\text { equipment }\end{array}$ & $\begin{array}{l}\text { Unfavourable economic situation in the sector } \\
\text { Ambitious investment plan } \\
\text { Forced succession (year 1) and succession due to retirement (year } 8 \text { ) }\end{array}$ \\
\hline & Firm 3 & Incertainty & Electricity & $\begin{array}{l}\text { Public enterprise } \\
\text { New legal environment to liberalize the sector }\end{array}$ \\
\hline & Firm 4 & Stable & Banking & Large geographic expansion \\
\hline \multirow{2}{*}{$\begin{array}{l}\text { Succession - no TMT } \\
\text { turnover }\end{array}$} & Firm 5 & Stable & Foodstuffs & Considerable growth through acquisitions \\
\hline & Firm 6 & Stable & Drinks and tobacco & $\begin{array}{l}\text { Unfavourable economic situation in the sector nationwide } \\
\text { International growth (acquisitions, alliances, joint ventures) } \\
\text { Quality assurance policy (specified place of origin for wines) }\end{array}$ \\
\hline \multirow[t]{2}{*}{$\begin{array}{l}\text { No succession - TMT } \\
\text { turnover }\end{array}$} & Firm 7 & Incertainty & $\begin{array}{l}\text { Equipment production and } \\
\text { assembly }\end{array}$ & $\begin{array}{l}\text { Commitment to quality } \\
\text { Placed as head of the group } \\
\text { Highest degree of TMT turnover: executive vice president }\end{array}$ \\
\hline & Firm 8 & Stable & Foodstuffs & $\begin{array}{l}\text { Top management main shareholders } \\
\text { Senior managers with severance protection clauses }\end{array}$ \\
\hline \multirow[t]{2}{*}{ No change } & Firm 9 & Stable & Foodstuffs & $\begin{array}{l}\text { Products innovated through acquisitions } \\
\text { The growth does not result in reorientation, the former policy seems to } \\
\text { continue in force }\end{array}$ \\
\hline & Firm 10 & Incertainty & Other consumer goods & Focus strategy: a subsidiary as head of the group \\
\hline
\end{tabular}

Note. TMT = top management team. 
observations for each type of change, thereby enriching the analysis and facilitating conclusions. The subperiods were chosen because of a certain degree of continuity in the events within each period and specific discontinuities at the frontiers of the time frame (Langley, 1999; Langley, Smallman, Tsoukas, $\&$ Van de Ven, 2013). Table 2 shows the selected firms, their classification in terms of the managerial changes they have undergone and the fundamental characteristics of each one.

Having selected the cases, in reference to earlier studies (Miller, 1993; Romanelli \& Tushman, 1994; Rindova, Ferrier \& Wiltbank, 2010; Durukan, Ozkan, \& Dalkilic, 2012), we used information published in the press about each of the companies to detect strategic changes. As Klarner and Raisch pointed out, these archival data provide 'consistent information for longitudinal studies, but data from questionnaires and interviews can be contaminated by the "biased recall” of respondents' (2013: 165).

Strategic change includes modifications in strategy, structure, power distribution and control systems. Following an exhaustive review of the literature on strategic change, as well as the measures added by different authors, these four factors were assessed as follows:

- Strategy changes were understood as modifications to one or more of 14 variables: price, product quality, quality of service, delivery time, degree of reaction to customer needs, product innovation, differentiation or exclusiveness of the product, structural or short-term company expansion, target sales, market share, advertising spending, company distribution system, and width of product range (Lant, Milliken, \& Batra, 1992).

- Structural changes included modifications to one or more of the following four variables: organization chart, subsidiary grouping criteria, business unit size and reorganization, and opening or closure of plants (Pitcher, Chreim, \& Kisfalvi, 2000). Another variable traditionally included as part of this group is the creation or the elimination of senior management positions (Tushman \& Rosenkopf, 1996). However, in our study, this event was considered a managerial change and is therefore omitted in this section.

- Power changes refer to change in the company's capital structure (Weisbach, 1988). Power distribution refers to changes in the shareholders, the board of directors and the TMT. Public firms publish annual information on the composition of their corporate governance bodies. Therefore, we only used the news items to identify changes in the company's capital structure (Weisbach, 1988).

- Changes in control systems involved modifications to one of more of the following variables: (i) incentive systems; (ii) budget (Barker, Patterson, \& Mueller, 2001); (iii) information systems (Lant, Milliken, \& Batra, 1992; Miller, 1993); (iv) inventory control (Lant, Milliken, \& Batra, 1992); (v) planning systems (Barker, Patterson, \& Mueller, 2001); and, (vi) administration expenses (Simons, 1994).

The source of this information was the Baratz database, which provides a summary of articles published in the main Spanish financial journals. In total, 3,909 news items were identified for the 10 firms in the sample. We also looked at any relevant facts held by the Madrid Stock Exchange relating to the period of our study, so as to corroborate the data, and compared them with the information from the Baratz database. The search for information was oriented towards content related to the parameters of strategic change - strategy, structure, power distribution and control system (Tushman \& Romanelli, 1985). This comparison between archival data sources showed that the relevant facts relate above all to the distribution of power with almost no reference to strategy, structure and control systems. Different data sources may perhaps provide different information (Gibbert \& Ruigrok, 2010). Accordingly, we created organizational event histories by reviewing information published in the press on each of the companies during the relevant time span.

Further studies have indicated that the relation between managers and strategic change is contingent, among other aspects, on the environment (Virany, Tushman, \& Romanelli, 1992; Tushman \& Rosenkopf, 1996), the industrial effect (Geletkanycz \& Hambrick, 1997) and the temporal effect 
(Adner \& Helfat, 2003). So, contextual data such as uncertainty in the industry and firm performance and size were collected. These data were extracted from information published in annual reports. Among the firms in the sample, six compete in stable business environments, while four others are innovative firms that compete in a business environment with greater uncertainty. Return on assets (ROA) was taken as the specific measure of performance, because it captures the degree to which top managers have effectively deployed firm assets (Geletkanycz \& Hambrick, 1997) and it is useful to value the effectiveness of the strategy of the firm (Oster, 1990). The ROA for 1992 and 2001 was also included in the study to evaluate both previous performance and performance after the changes to the firms that took place at the start and at the end of the period under analysis. Firm size was calculated by the logarithmic transformation of their sales volumes for each year. These data are shown in Tables 3 and 4.

\section{Data analysis}

A quantitative data analysis strategy was used to reduce the complex mass of information to a set of quantitative time series, in combination with synthetic strategy, so that we could deduce the sequences (Langley, 1999) between management change and strategic change.

We listed and coded qualitative incidents according to a predefined set of coding instructions on the parameters of strategic change (Appendix 1). In all, 3,909 news items were independently sorted by three coders (one author and another two experts who had not participated in the study). The coders developed a profile sheet for each company from information on the types of change or events under consideration (see Appendix 2). All news items in which a substantial change in any of these dimensions was observed were assigned a value of 1 in the appropriate category alongside the particular date; otherwise, a 0 was recorded. The various events concerning each company published in the press were sorted into chronological order. The coders then exchanged documents and wrote independent event histories. After this, the three classifications from each coder were compared. Silverman defined reliability as 'the degree of consistency with which instances are assigned to the same category by different observers' (2005: 2010). The lowest level of congruence between coders was 0.97. Disagreements were discussed and resolved. Their high level of congruency indicates construct validity and methodological reliability (Gibbert \& Ruigrok, 2010). Table 5 includes some examples of the news collected from the press and its coding for the purposes of this study.

\section{RESULTS AND DISCUSSION}

\section{Managerial change and strategic change}

Tables 3 and 4 contain chronological summaries of the most relevant events experienced within the company during the period under consideration, as well as the implications of each change that was observed. Managerial change and strategic change may take place in the same year. Given that quantitative studies usually evaluate the annual situation, the researcher might consider that these changes are simultaneous (Virany, Tushman, \& Romanelli, 1992; Barker \& Duhaime, 1997). This observation has led some authors to suggest that the term 'strategic change' implies that modifications have taken place simultaneously (Amis, Slack, \& Hinnings, 2004). By using the data from the news items, we were able to determine the order of precedence of the changes in the strategic change components within the firms. This information allowed us to establish the sequence of events that took place in each company over the entire length of the study. The information shown in Tables 4 and 5 is reflected in Tables 6 and 7 in a particular order. Table 6 only includes the firm-period in which four parameter of strategic change were modified: the firm-period in which strategic change took place. Table 7 shows the firm-period in which no strategic change took place. 
Table 3. Chronological summaries of the most relevant events of the sample firms (Firms 1-6)

\begin{tabular}{|c|c|c|c|c|c|c|c|c|c|c|}
\hline & Type & Share & Board & CEO & TMT change ${ }^{b}$ & Strategy & Structure & Control & Size & $R O A$ \\
\hline \multicolumn{11}{|l|}{ Firm 1} \\
\hline \multicolumn{11}{|l|}{ Stable } \\
\hline Year 1 & 1 & $\mathrm{x}$ & $x$ & & & & & & 3.5 & 18.19 \\
\hline Year 2 & & & & & Reorganization & Expansion & Organization chart & & 3.8 & 15.56 \\
\hline Year 3 & & & & & & Innovations & New plants opening & $x$ & 4.0 & 22.64 \\
\hline Year 4 & 2 & & $x$ & & Turnover & & New plants opening & & 5.1 & 26.61 \\
\hline Year 5 & 4 & $\mathrm{x}$ & & $x$ & Turnover & Internet distribution & & & 5.2 & 25.45 \\
\hline Year 6 & & & & & Reorganization & Diversification & Business unit reorganized & $\mathrm{x}$ & 5.4 & 22.03 \\
\hline Year 7 & 4 & $\mathrm{x}$ & $x$ & $\mathrm{x}$ & Turnover & Internet distribution & New business unit & & 5.5 & 16.97 \\
\hline Year 8 & & $x$ & $\mathrm{x}$ & & Reorganization & 1st diversification not related & Organization chart & $\mathrm{x}$ & 5.5 & 9.89 \\
\hline \multicolumn{11}{|c|}{ 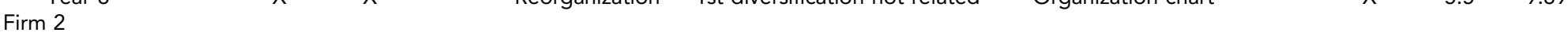 } \\
\hline Incertainty & & & & & & & & & & \\
\hline Year 1 & 4 & $\mathrm{x}$ & & & & & & & 6.5 & 1.95 \\
\hline Year 2 & & & $\mathrm{x}$ & $\mathrm{x}$ & Reorganization & New services and products & Grouping criteria & $x$ & 6.6 & 2.42 \\
\hline Year 3 & 2 & & & & & Outsourcing & & & 6.5 & 2.60 \\
\hline Year 4 & & & & & Turnover & Quality assurance & Business unit size & & 6.6 & 2.89 \\
\hline Year 5 & 0 & & & & & & & & 6.7 & 2.81 \\
\hline Year 6 & 2 & & $\mathrm{x}$ & & Turnover & Distribution & Autonomous plants closing & & 6.8 & 3.38 \\
\hline Year 7 & & & & & & & Business unit size & & 6.9 & 3.50 \\
\hline Year 8 & 4 & & $x$ & $x$ & Reorganization & $R \& D$ & Organization chart & $x$ & 6.9 & 3.66 \\
\hline \multicolumn{11}{|l|}{ Firm 3} \\
\hline Incertainty & & & & & & & & & & \\
\hline Year 1 & 0 & & & & & & & & 5.5 & 0.06 \\
\hline Year 2 & 1 & $x$ & & & Reorganization & Diversifications and exports & Business unit reorganized & $\mathrm{x}$ & 5.5 & 0.05 \\
\hline Year 3 & 2 & & & & Turnover & Exports & & & 5.7 & 0.06 \\
\hline Year 4 & & & $x$ & & & & Business unit size & & 5.7 & 0.05 \\
\hline Year 5 & 4 & $x$ & & $x$ & Turnover & & & & 5.6 & 0.05 \\
\hline Year 6 & & & & & Reorganization & Internationalization & New business lines & $x$ & 5.7 & 0.07 \\
\hline Year 7 & 2 & $x$ & & & & New products & & & 5.7 & 0.08 \\
\hline Year 8 & & & $x$ & & Turnover & & New plants opening & & 5.8 & 0.37 \\
\hline \multirow{2}{*}{\multicolumn{11}{|c|}{$\begin{array}{l}\text { Firm } 4 \\
\text { Stable }\end{array}$}} \\
\hline & & & & & & & & & & \\
\hline Year 1 & 0 & $\mathrm{x}$ & & & & New products & & & 4.7 & 0.83 \\
\hline Year 2 & & $x$ & $x$ & & & & & & 4.5 & 0.06 \\
\hline Year 3 & 3 & $x$ & & & & & Business unit size & & 4.6 & 0.30 \\
\hline Year 4 & & & $x$ & & Both & Growth and quality & Grouping criteria & $x$ & 4.8 & 0.67 \\
\hline Year 5 & 3 & $x$ & $\mathrm{x}$ & & & Distribution & Business unit size & & 4.7 & 0.85 \\
\hline
\end{tabular}


TABLE 3 (Continued)

\begin{tabular}{|c|c|c|c|c|c|c|c|c|c|c|}
\hline & Type $e^{a}$ & Share & Board & CEO & TMT change $e^{b}$ & Strategy & Structure & Control & Size & ROA \\
\hline Year 6 & & & $x$ & & Both & Focus & Business unit reorganized & $x$ & 4.6 & 1.07 \\
\hline Year 7 & 4 & $x$ & $x$ & $x$ & Reorganization & Innovations and low prices & Organization chart & & 4.6 & 1.03 \\
\hline Year 8 & & & $x$ & & Reorganization & & Business unit size & $x$ & 4.6 & 0.39 \\
\hline \multicolumn{10}{|l|}{ Firm 5} & \\
\hline Year 1 & 0 & & & & & Expansion & & & 4.6 & 0.83 \\
\hline Year 2 & & & & & & Low prices & & & 4.5 & 0.55 \\
\hline Year 3 & 4 & & $x$ & & & & New subsidiaries & & 4.9 & 0.81 \\
\hline Year 4 & & & $x$ & $x$ & Reorganization & Internationalization & Organization chart & $x$ & 4.9 & 0.77 \\
\hline Year 5 & 0 & & & & & New products & & & 4.9 & 0.72 \\
\hline Year 6 & & & & & & Quality products & Business unit size & & 5.0 & 0.79 \\
\hline Year 7 & 1 & & $x$ & & & & & & 5.0 & 0.66 \\
\hline Year 8 & & & & & Reorganization & Diversifications and advertising & Business unit reorganized & $x$ & 5.3 & 0.65 \\
\hline \multicolumn{11}{|c|}{ 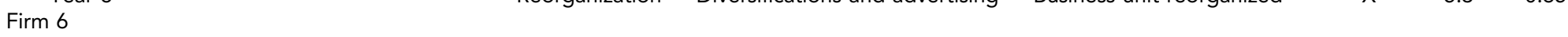 } \\
\hline Stable & & & & & & & & & & \\
\hline Year 1 & 0 & $\mathrm{x}$ & & & & Quality wines & & & 5.2 & 0.96 \\
\hline Year 2 & & $x$ & $X$ & & & & Business unit size & & 5.2 & 0.86 \\
\hline Year 3 & 1 & & $x$ & & Reorganization & & Business unit size & & 5.3 & 0.89 \\
\hline Year 4 & & & & & & Diversifications & New plants & $x$ & 5.3 & 0.91 \\
\hline Year 5 & 4 & & $x$ & $x$ & Reorganization & Direct foreign investment & Business unit reorganized & & 5.3 & 1.04 \\
\hline Year 6 & & $x$ & $x$ & & Reorganization & Market share & Business unit size & $x$ & 5.3 & 0.98 \\
\hline Year 7 & 1 & $x$ & $x$ & & Reorganization & Innovations and quality & & $x$ & 5.3 & 0.74 \\
\hline Year 8 & & $x$ & & & Reorganization & Growth & Organization chart & & 5.3 & 0.62 \\
\hline
\end{tabular}

Note.

${ }^{\mathrm{a}}$ Top management team (TMT) changes typologies: 1, reorganization; 2, turnover; 3, turnover + reorganization; 4, Chief Executive Officer (CEO) + reorganization;

5, CEO + turnover; 0, no TMT changes.

both: reorganization and turnover. 
Table 4. Chronological summaries of the most relevant eVents of the sample firms (Firms 7-10)

\begin{tabular}{|c|c|c|c|c|c|c|c|c|c|c|}
\hline & Type $e^{a}$ & Share & Board & CEO & TMT change $e^{b}$ & Strategy & Structure & Control & Size & $R O A$ \\
\hline \multicolumn{11}{|l|}{ Firm 7} \\
\hline \multicolumn{11}{|l|}{ Incertainty } \\
\hline Year 1 & 0 & & & & & Quality & & & 5.5 & 0.22 \\
\hline Year 2 & 3 & & & & Both & New products & Business unit reorganized & $\mathrm{X}$ & 5.5 & 0.223 \\
\hline Year 3 & 0 & & $x$ & & & New products & Business unit size & & 5.5 & 0.188 \\
\hline Year 4 & & & & & & Focus on service & Business units size & & 5.5 & 1.15 \\
\hline Year 5 & 0 & & & & & & Business unit size & & 5.6 & 1.09 \\
\hline Year 6 & & & & & & & New plants & & 5.6 & 1.13 \\
\hline Year 7 & 3 & & $x$ & & Reorganization & & Business units reorganized & & 5.6 & 1.07 \\
\hline Year 8 & & & $x$ & & Turnover & New services & & $X$ & 5.7 & 1.1 \\
\hline \multirow{2}{*}{\multicolumn{11}{|c|}{$\begin{array}{l}\text { Firm } 8 \\
\text { Stable }\end{array}$}} \\
\hline Stable & & & & & & & & & & \\
\hline Year 1 & 2 & $\mathrm{X}$ & & & & Quality & & & 5.2 & 10.52 \\
\hline Year 2 & & $x$ & & & & & Business unit size & & 5.3 & 8.19 \\
\hline Year 3 & & $\mathrm{X}$ & $\mathrm{X}$ & & Turnover & Internationalization & & & 5.3 & 3.71 \\
\hline Year 4 & 5 & $x$ & $x$ & & & & & & 5.3 & 3.3 \\
\hline Year 5 & & & & $x$ & Turnover & New outlets & & & 5.3 & 1.71 \\
\hline Year 6 & & & & & & New products & Business unit size & & 5.4 & 7.28 \\
\hline Year 7 & 0 & & & & & & & & 5.4 & 6.44 \\
\hline Year 8 & 0 & $x$ & & & & Quality and distribution & & & 5.4 & 6.12 \\
\hline \multirow{2}{*}{\multicolumn{11}{|c|}{$\begin{array}{l}\text { Firm } 9 \\
\text { Stable }\end{array}$}} \\
\hline & & & & & & & & & & \\
\hline Year 1 & 0 & & & & & Growth & Business unit size & & 5.5 & 0.95 \\
\hline Year 2 & 1 & $x$ & & & & & & & 5.5 & 0.91 \\
\hline Year 3 & & & & & Reorganization & New products & Business unit reorganized & $x$ & 5.6 & 0.82 \\
\hline Year 4 & 0 & & $x$ & & & Quality & & & 5.6 & 0.89 \\
\hline Year 5 & & $x$ & $x$ & & & Delivery lead-times & New plants & & 5.6 & 0.83 \\
\hline Year 6 & & $x$ & & & & & & & 5.6 & 0.94 \\
\hline Year 7 & 1 & $x$ & & & & & & & 5.7 & 0.98 \\
\hline Year 8 & & & $x$ & & Reorganization & International growth & Business unit reorganized & $x$ & 5.9 & 1.18 \\
\hline \multirow{2}{*}{\multicolumn{11}{|c|}{$\begin{array}{l}\text { Firm } 10 \\
\text { Incertainty }\end{array}$}} \\
\hline & & & & & & & & & & \\
\hline Year 1 & 0 & $x$ & & & & Business unit sale & Business unit size & & 4.5 & 0.11 \\
\hline Year 2 & & $x$ & $x$ & & & & Plants closing & & 4.5 & 0.3 \\
\hline Year 3 & & $x$ & $x$ & & & & & & 4.6 & 0.35 \\
\hline Year 4 & 0 & & & & & Innovations & & & 4.6 & 0.34 \\
\hline Year 5 & 0 & & $x$ & & & & & & 4.6 & 0.39 \\
\hline Year 6 & & $x$ & $x$ & & & New patents & & & 4.7 & 0.39 \\
\hline Year 7 & 1 & $x$ & & & Reorganization & Focus on pharmamar & & & 4.8 & 0.38 \\
\hline Year 8 & & $x$ & & & & New products & Organization chart & $x$ & 4.9 & 0.16 \\
\hline
\end{tabular}

Note.

${ }^{a}$ Top management team (TMT) changes typologies: 1, reorganization; 2, turnover; 3, turnover + reorganization; 4, Chief Executive Officer (CEO) + reorganization; 5, CEO + turnover; 0 , no TMT changes.

G both: reorganization and turnover. 
Table 5. Examples of data collection of news

\begin{tabular}{|c|c|c|c|c|}
\hline News & Strategy & Structure & Power & Control \\
\hline The firm has opened a new branch to diversify its activities & Innovation & Business unit size & & \\
\hline $\begin{array}{l}\text { In July } 2014 \text {, the firm opened the first shop in Belgium, the first } \\
\text { non-Mediterranean country in the EU where the firm has set up } \\
\text { activities }\end{array}$ & Sales turnover & $\begin{array}{l}\text { Plants opening or } \\
\text { closure }\end{array}$ & & \\
\hline $\begin{array}{l}\text { The chairman of the firm has created a General Manager position in } \\
\text { order to discharge some of the management responsibilities that } \\
\text { he had exclusively exercised up until now. Before, the } \\
\text { organization chart was distributed to different area managers who } \\
\text { were directly supervised by the chairman }\end{array}$ & & Organization chart & & \\
\hline $\begin{array}{l}\text { A banking entity has signed the agreement to buy } 18 \% \text { of the } \\
\text { capital of the firm }\end{array}$ & & & Share capital & \\
\hline $\begin{array}{l}\text { The firm has invested } 400 \text { million in One World Software to adapt } \\
\text { the economic and financial information to a new currency (Euro) }\end{array}$ & & & & Information system \\
\hline $\begin{array}{l}\text { The firm has opened the first establishment in Morocco where its } \\
\text { group has had a factory since } 1999\end{array}$ & & $\begin{array}{l}\text { Plants opening or } \\
\text { closure }\end{array}$ & & \\
\hline $\begin{array}{l}\text { The firm has bought } 767.7 \text { million pesetas, } 84.75 \% \text { of the capital of } \\
\text { its supplier Luxor. This operation is to reduce cost, as the product } \\
\text { of Luxor is what increases the cost of the pizzas }\end{array}$ & Structural growth & Business unit size & & Budgets \\
\hline \multicolumn{5}{|l|}{$\begin{array}{l}\text { The firm has redefined the strategic position to compete in prices } \\
\text { with its competitors }\end{array}$} \\
\hline The firm has begun to commercialize its products on internet & Distribution & & & \\
\hline $\begin{array}{l}\text { The firm has signed a contract to develop and introduce the use of } \\
\text { fire resistant materials, in order to offer additional safety to the } \\
\text { user }\end{array}$ & Quality product & & & \\
\hline $\begin{array}{l}\text { The firm has introduced the EMS (an environmental management } \\
\text { system) to obtain ISO } 14001 \text { certification. To do so, the firm has an } \\
\text { environmental assessment team at each of its regional branches in } \\
\text { charge of centralizing the information used to set up the system } \\
\text { and to establish controls over the whole process }\end{array}$ & Quality process & & & Information system \\
\hline $\begin{array}{l}\text { The firm has advanced with its integration process through the } \\
\text { presentation of its new corporate identity which merges the two } \\
\text { company logos }\end{array}$ & Advertising & & & \\
\hline $\begin{array}{l}\text { The firm has developed a new international purchasing system to } \\
\text { centralize all the offers from its Spanish, Portuguese and American } \\
\text { suppliers }\end{array}$ & & & & Stock control \\
\hline
\end{tabular}

Note: EMS = environment management system. 
TABle 6. Firm-Periods With StRAtegic Change

\begin{tabular}{|c|c|c|c|c|c|c|}
\hline Type ${ }^{a}$ & Share & Board & Strategy & Structure & Control & Strategic change \\
\hline \multirow[t]{3}{*}{1} & \multirow[t]{3}{*}{$x$} & \multirow[t]{3}{*}{$\mathrm{x}$} & & & & \multirow[t]{3}{*}{ Yes } \\
\hline & & & Expansion & Organization chart & & \\
\hline & & & Innovations & New plants opening & $\mathrm{x}$ & \\
\hline 1 & \multirow[t]{3}{*}{$\mathrm{x}$} & \multirow{3}{*}{$x$} & Diversifications and exports & Business unit reorganized & $\mathrm{X}$ & Yes \\
\hline \multirow[t]{2}{*}{1} & & & & & & \multirow[t]{2}{*}{ Yes } \\
\hline & & & Diversifications and advertising & Business unit reorganized & $\mathrm{x}$ & \\
\hline \multirow[t]{2}{*}{1} & & \multirow[t]{2}{*}{$\mathrm{x}$} & & Business unit size & & \multirow[t]{2}{*}{ Yes } \\
\hline & & & Diversifications & New plants & $\mathrm{x}$ & \\
\hline \multirow[t]{2}{*}{1} & $\mathrm{x}$ & \multirow[t]{2}{*}{$x$} & Innovations and quality & & $\mathrm{x}$ & \multirow[t]{2}{*}{ Yes } \\
\hline & $\mathrm{X}$ & & Growth & Organization chart & & \\
\hline \multirow[t]{2}{*}{1} & $\mathrm{x}$ & & & & & \multirow[t]{2}{*}{ Yes } \\
\hline & & & New products & Business unit reorganized & $\mathrm{x}$ & \\
\hline \multirow[t]{2}{*}{1} & $\mathrm{x}$ & & & & & \multirow[t]{2}{*}{ Yes } \\
\hline & & $\mathrm{X}$ & International growth & Business unit reorganized & $\mathrm{x}$ & \\
\hline \multirow[t]{4}{*}{1} & $\mathrm{x}$ & & Focus on pharmamar & & & \multirow[t]{4}{*}{ Yes } \\
\hline & $\mathrm{x}$ & & New products & Organization chart & $\mathrm{x}$ & \\
\hline & $x$ & & & Business unit size & & \\
\hline & $\mathrm{X}$ & $\mathrm{x}$ & Internationalization & & & \\
\hline \multirow[t]{2}{*}{3} & $x$ & & & Business unit size & & \multirow[t]{2}{*}{ Yes } \\
\hline & & $\mathrm{x}$ & Growth and quality & Grouping criteria & $\mathrm{x}$ & \\
\hline \multirow[t]{2}{*}{3} & $\mathrm{x}$ & $\mathrm{x}$ & Distribution & Business unit size & & \multirow[t]{2}{*}{ Yes } \\
\hline & & $\mathrm{x}$ & Focus & Business unit reorganized & $\mathrm{x}$ & \\
\hline \multirow{3}{*}{$\begin{array}{l}3 \\
3\end{array}$} & & $\mathrm{x}$ & New products & Business unit reorganized & $\mathrm{x}$ & Yes \\
\hline & & $\mathrm{X}$ & & Business units reorganized & & Yes \\
\hline & & $\mathrm{x}$ & New services & & $\mathrm{X}$ & \\
\hline 4 & $\mathrm{X}$ & & Internet distribution & & & Yes \\
\hline & & & Diversification & Business unit reorganized & $\mathrm{x}$ & \\
\hline 4 & $\mathrm{x}$ & $\mathrm{x}$ & Internet distribution & New business unit & & Yes \\
\hline & $x$ & $x$ & 1st diversification not related & Organization chart & $x$ & \\
\hline 4 & $x$ & & & & & Yes \\
\hline & & $x$ & New services and products & Grouping criteria & $x$ & \\
\hline 4 & & $x$ & $R \& D$ & Organization chart & $x$ & Yes \\
\hline 4 & $\mathrm{x}$ & & & & & Yes \\
\hline & & & Internationalization & New business lines & $\mathrm{x}$ & \\
\hline 4 & $\mathrm{x}$ & $\mathrm{x}$ & Innovations and low prices & Organization chart & & Yes \\
\hline & & $\mathrm{x}$ & & Business unit size & $\mathrm{x}$ & \\
\hline 4 & & $x$ & & New subsidiaries & & Yes \\
\hline & & $\mathrm{x}$ & Internationalization & Organization chart & $\mathrm{x}$ & \\
\hline 4 & & $\mathrm{x}$ & Direct foreign investment & Business unit reorganized & & Yes \\
\hline & $\mathrm{x}$ & $\mathrm{x}$ & Market share & Business unit size & $\mathrm{x}$ & \\
\hline
\end{tabular}

Note.

${ }^{\text {aT }}$ op management team (TMT) changes typologies: 1, reorganization; 3, turnover + reorganization; 4, Chief Executive Officer (CEO) + reorganization; 5, CEO + turnover.

No strategic change was observed in the firms in which only TMT turnover had taken place, with neither CEO succession nor reorganization (Type 2 in Tables 6 and 7). Nevertheless, this was not the case for the firms that had experienced TMT reorganization without CEO succession (Type 1 in Table 7). In this regard, it should be noted that other firms, which developed strategic changes had all reorganized their management teams (Types 1, 3 and 4 in Table 6). Conversely, firms that did not undergo strategic change had no TMT reorganization (Types 2, 5 and 0 in Table 7). These findings suggest that TMT reorganization appears to be necessary to induce strategic reorientation, because it 
Marta Domínguez-CC and Carmen Barroso-Castro

TABle 7. Firm-periods Without Strategic ChANGe

\begin{tabular}{|c|c|c|c|c|c|c|}
\hline Type & Share & Board & Strategy & Structure & Control & Strategic change \\
\hline 2 & & $x$ & & New plants opening & & No \\
\hline 2 & & & Outsourcing & & & No \\
\hline 2 & & $x$ & Distribution & $\begin{array}{l}\text { Business unit size } \\
\text { Autonomous plants closing } \\
\text { Business unit size }\end{array}$ & & No \\
\hline 2 & & & Exports & & & No \\
\hline 2 & $x$ & $x$ & New products & $\begin{array}{l}\text { Business unit size } \\
\text { New plants opening }\end{array}$ & & No \\
\hline 2 & $x$ & & Quality & & & No \\
\hline 5 & $x$ & $x$ & $\begin{array}{l}\text { New outlets } \\
\text { New products }\end{array}$ & Business unit size & & No \\
\hline 0 & & & & & & No \\
\hline 0 & & & & & & No \\
\hline 0 & $\begin{array}{l}x \\
x\end{array}$ & $x$ & New products & & & No \\
\hline 0 & & & $\begin{array}{l}\text { Expansion } \\
\text { Low prices }\end{array}$ & & & No \\
\hline 0 & & & $\begin{array}{l}\text { New products } \\
\text { Quality products }\end{array}$ & Business unit size & & No \\
\hline 0 & $\begin{array}{l}x \\
x\end{array}$ & $x$ & Quality wines & Business unit size & & No \\
\hline 0 & & & Quality & & & No \\
\hline 0 & & $x$ & $\begin{array}{l}\text { New products } \\
\text { Focus on service }\end{array}$ & $\begin{array}{l}\text { Business unit size } \\
\text { Business units size }\end{array}$ & & No \\
\hline 0 & & & & $\begin{array}{l}\text { Business unit size } \\
\text { New plants }\end{array}$ & & No \\
\hline 0 & & & & & & No \\
\hline 0 & $x$ & & Quality and distribution & & & No \\
\hline 0 & & & Growth & Business unit size & & No \\
\hline 0 & $\begin{array}{l}x \\
x\end{array}$ & $\begin{array}{l}x \\
X\end{array}$ & $\begin{array}{l}\text { Quality } \\
\text { Delivery lead-times }\end{array}$ & New plants & & No \\
\hline 0 & $\begin{array}{l}x \\
x \\
x\end{array}$ & $\begin{array}{l}x \\
x\end{array}$ & Business unit sale & $\begin{array}{l}\text { Business unit size } \\
\text { Plants closing }\end{array}$ & & No \\
\hline 0 & & & Innovations & & & No \\
\hline 0 & & $x$ & & & & No \\
\hline & $\mathrm{x}$ & $\mathrm{x}$ & New patents & & & \\
\hline
\end{tabular}

Note.

${ }^{\mathrm{a}}$ Top management team (TMT) changes typologies: 2, turnover; 5, CEO + turnover; 0, no TMT changes.

always precedes strategic change. In fact, none of the firms in this study would be able to initiate strategic change through $\mathrm{CEO}$ succession alone. So, CEO succession was perhaps not the main determining factor of strategic change in the firms under study. The change in the set of resources and capabilities of the TMT, when only the CEO changes, is not sufficient in itself to initiate strategic change. Some papers have described how major changes in the firms can occur even in the absence of CEO succession (Virany, Tushman, \& Romanelli, 1992). These findings might reflect the complexity of modern companies, whereby any single individual, even a CEO, is unable to impose significant 
change without an accompanying change in TMT (Pfeffer, 1981; Hambrick \& Mason, 1984; Wiersema \& Bantel, 1992).

Our study has identified a new measurement of management change - reorganization - which has not been used in prior studies. Managerial reorganization does not necessarily imply a change of the TMT members. Rather, it refers to a reshuffling of responsibilities that perhaps involve the same people. The findings of this study suggest that a reorganization of responsibilities might be sufficient to prompt change, without altering the composition of the TMT. Reorganization is a new typology of change in the TMT that manifests itself in a new arrangement of TMT capabilities. From the point of view of the resource- and capability-based theory, reorganization does not imply immediate renovation of the set of resources and skills of top managers. But the new combination of human capital, social capital and cognition, following the reorganization of the posts in the TMT, can strengthen the capability of the firm to initiate strategic change. Change occurs when the directors face new experiences or new interactions with the business environment, which allows them to pursue new possible lines of action (Tsoukas \& Chia, 2002). Even though they participate in similar functional or business areas, each manager will make a personal assessment of the correct course of action, so their decisions on content and timing will vary (Adner \& Helfat, 2003). When reorganizing the knowledge and capabilities of the managers, by assigning them other roles, it is possible to overcome inertia and resistance to change. On assuming a new post with new responsibilities, managers who analyse the business environment from a different functional perspective will lend it greater attention. The value of a resource that may have been overlooked can increase when exploited in another way (Newbert, 2008), as managers can acquire some knowledge and develop expertize and abilities through work experience (Bailey and Helfat, 2003). Accordingly, top managers acquire new human capital via learning and experience (Adner \& Helfat, 2003) in their new posts. Therefore, TMT reorganization will facilitate the discovery of new opportunities in the business setting, provoking strategic change.

On the basis of the above analysis, the following propositions may now be advanced:

Proposition 1a: Managerial change precedes strategic change in firms that are seeking to adapt strategically to their environments.

Proposition 1b: TMT reorganization is a sufficient condition to provoke strategic change.

In this study, whenever CEO succession took place, subsequent TMT reorganization and sometimes TMT turnover were observed. These results reflect those of previous studies (Kesner \& Dalton, 1994; Shen \& Cannella, 2002). This change in managerial arrangements occurred regardless of whether the $\mathrm{CEO}$ successor was an outsider or an insider, or whether the change was forced or voluntary.

\section{Strategic change}

Our analysis of 3,909 press items showed that there are some rare periods with no change. All of the companies had made frequent modifications to their strategy and structure (Tables 3 and 4). In fact, changes in both strategy and in strategy and structure occurred on many occasions, on the same calendar date. This information supports the thesis of continuous change and the vision of the organization, as emerging patterns arise of continuous adaptation to the business environment (Tsoukas \& Chia, 2002). Changes in power distribution were also very frequent, but we think that these changes are more customary in this sample, because it consisted of listed firms. Some authors have suggested that the term 'strategic change' implies that modifications in company strategy, structure, power distribution and control system have taken place within a certain time - for instance, within a period of no longer than 2 years (Tushman \& Romanelli, 1985; Romanelli \& Tushman, 1994; Gordon et al., 2000). However, we have adopted the view in the present study that the key 
consideration should not be time. Instead, it should be the magnitude of change taking place in the company (Amis, Slack, \& Hinnings, 2004). We considered the magnitude of strategic change in terms of the content and scope of the change that takes place. According to some authors (Romanelli \& Tushman, 1994), strategic change implies modifications in strategy, structure, power distribution and control. In Tables 6 and 7, the changes that occurred are grouped by whether they modified the four parameters of change or, in other words, whether strategic change took place. Adopting this criterion, the qualitative analysis in this study revealed that each time the four parameters were modified in a related way, companies shared a series of specific changes in both strategy (aspects linked to the company's growth and innovation) and structure (the firm's organization chart and subsidiary grouping criteria). The reorganization was needed for strategic change to takes place. The new use of TMT knowledge and capabilities permits strategic reorientation, because TMT capabilities are dynamic over time. (Adner \& Helfat, 2003). Furthermore, all human capital is transferable when top managers remain in the same firm (Harris \& Helfat, 1997). Therefore, new challenges faced by managers in their new roles increase their human capital. When managers access new posts, the differences in the human capital that they bring with them and those that they acquire at work (Adner $\&$ Helfalt, 2003) become evident. The reorganization of roles means that top managers have a broader view of the firm, linking experience acquired in their earlier post to the challenges in their new role. Besides, strategic change gives managers an opportunity to move organizations into strategic areas in which they can exercise their expertize and talents (Greve \& Mitsuhashi, 2007). The possibility of exploiting all TMT capabilities - generic, industry-specific, firm-specific and related industry skills - at the same time as overcoming organizational inertia through reorganization, may help a TMT to detect synergies that favour innovation and growth in the firm. The appointment of managers to post that best suit their potential can facilitate the strategic fit between the firm and the business environment (Gordon et al., 2000; Bigley \& Wiersema, 2002; Jarzabkowski, 2003; Greve \& Mitsuhashi, 2007; Brauer, 2009). Additionally, the reorganization helps to explain the importance of outliner structural changes. A new arrangement of senior posts that is implicit in reorganization will necessarily be reflected in the organigram of the firm and will probably be linked to the creation of new strategyrelated business units. On the contrary, changes in the composition of the team are not usually reflected in the organigram of the firm, because only the senior management changes, while the posts remain unchanged. Accordingly, if we are to consider that strategic change has taken place, it would appear necessary to identify these specific modifications in strategy and structure that support the intrinsic link between TMT reorganization and strategic change. In formal terms, this proposition can be expressed as follows:

Proposition 2: Strategic change that follows TMT reorganization implies modifications (as necessary evidence) of both its strategy (growth and/or innovation) and its structure (an organizational chart and/ or subsidiary grouping criteria and/or business units that are reorganized), which must be accompanied by a change in both its power distribution and its control systems (sufficient condition).

The proposed model that connects the above propositions is summarized in Figure 1.

If we group the types of change that occurred in the competitive business environment of the firms (Table 8), we see that the firms used TMT reorganization in an isolated way (six times) or combined with turnover and/or CEO (13 periods in total), in a stable environment. On the contrary, turnover was used more often in uncertain business environments, where one type of change takes place (four times); although this number was too small to generalize. Moreover, if uncertainty exists in the business environment, changes in top management generally have a positive influence on performance. On the contrary, if the environment is stable, changes in top management are usually negative for ROA except when TMT reorganization is the only change. Our analysis shows that managerial change precedes strategic change. Therefore, we may say that if strategic change is solely initiated through the 
Managerial change and strategic change

Table 8. Types of managerial Change AND enVironment. efFects on Performance

\begin{tabular}{|c|c|c|c|}
\hline Environment & Managerial changes ${ }^{a}$ & $R O A-1$ & $R O A+1$ \\
\hline \multirow[t]{5}{*}{ Stable } & Reorganization & $\begin{array}{l}\text { Decrease } \\
\text { Increase } \\
\text { Decrease } \\
\text { Decrease } \\
\text { Decrease } \\
\text { Increase }\end{array}$ & $\begin{array}{l}\text { Increase } \\
\text { Constant } \\
\text { Increase } \\
\text { Increase } \\
\text { Increase } \\
\text { Increase }\end{array}$ \\
\hline & Turnover & $\begin{array}{l}\text { High } \\
\text { increase } \\
\text { Decrease } \\
\text { Decrease }\end{array}$ & $\begin{array}{l}\text { Decrease } \\
\text { Decrease } \\
\text { Decrease }\end{array}$ \\
\hline & CEO and both & $\begin{array}{l}\text { Increase } \\
\text { Decrease }\end{array}$ & $\begin{array}{l}\text { Decrease } \\
\text { Increase }\end{array}$ \\
\hline & Both & $\begin{array}{l}\text { Decrease } \\
\text { Increase }\end{array}$ & $\begin{array}{l}\text { Increase } \\
\text { Decrease }\end{array}$ \\
\hline & CEO + reorganization & $\begin{array}{l}\text { Increase } \\
\text { Increase } \\
\text { Increase }\end{array}$ & $\begin{array}{l}\text { Decrease } \\
\text { Decrease } \\
\text { Decrease }\end{array}$ \\
\hline \multirow[t]{5}{*}{ Incertainty } & CEO + reorganization & $\begin{array}{l}\text { Increase } \\
\text { Increase }\end{array}$ & $\begin{array}{l}\text { Increase } \\
\text { Increase }\end{array}$ \\
\hline & Turnover & $\begin{array}{l}\text { Increase } \\
\text { Decrease } \\
\text { Decrease } \\
\text { Increase }\end{array}$ & $\begin{array}{l}\text { Decrease } \\
\text { Increase } \\
\text { Constant } \\
\text { Increase }\end{array}$ \\
\hline & Reorganization & $\begin{array}{l}\text { Constant } \\
\text { Constant }\end{array}$ & $\begin{array}{l}\text { Constant } \\
\text { Increase }\end{array}$ \\
\hline & CEO and both & Constant & Increase \\
\hline & Both & $\begin{array}{l}\text { Constant } \\
\text { Increase }\end{array}$ & $\begin{array}{l}\text { Decrease } \\
\text { Decrease }\end{array}$ \\
\hline
\end{tabular}

${ }^{\mathrm{a} B o t h}$ : reorganization and turnover.

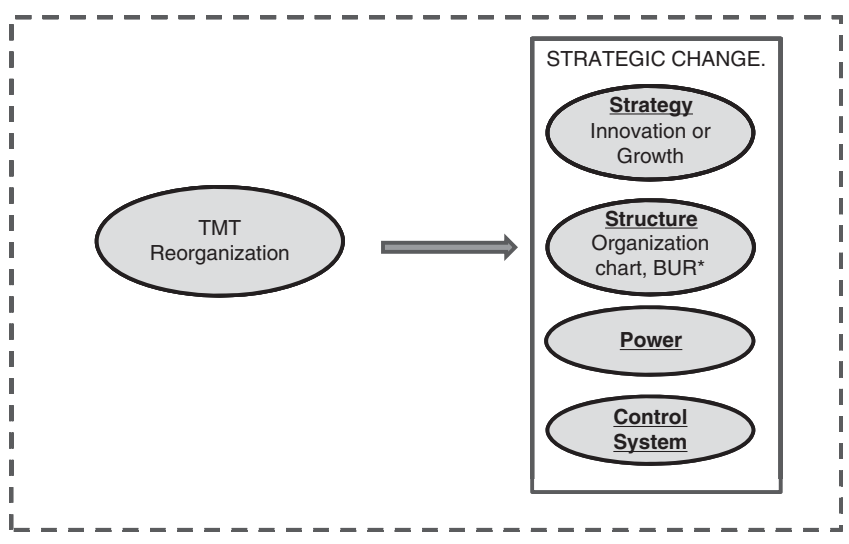

Figure 1. THEORETICAL MODEL

NOTE. BUR = BUSINESS UNIT REORGANIZATION 
reorganization of the management team, it always has a positive effect on ROA. It is striking that ROA subsequently diminishes in stable environments, if the reorganization is used in combination with $\mathrm{CEO}$ succession to initiate strategic change. However, if the environment is uncertain, the combination of CEO succession and reorganization to initiate strategic change subsequently improves ROA. In stable business environments, firms that exclusively use the reorganization of TMT to initiate strategic change appear to show improvements in their performance. In contrast, in turbulent business environments, firms that use both reorganization or CEO succession and reorganization to initiate strategic change appear to show improvements in their performance. Accordingly, some studies have pointed out that CEO succession (and subsequent modifications to the management team) can lead to a considerable improvement in business performance for the firm (Wiersema \& Bantel, 1993; Kesner \& Dalton, 1994; Castanias \& Helfat, 2001; Gong \& Wu, 2011). From the point of view of the resource- and capability-based theory, TMT reorganization helps to exploit all managerial capital, because all the capabilities are transferable within the same firm (Harris \& Helfat, 1997). This can explain our results that show better performance after reorganization, both in stable environments and in more dynamic environments if accompanied by CEO succession. However, more evidence on these issues is needed. Their development as future lines of investigation would therefore be of interest.

Other possible future avenues of research relate to the board. Changes in the management team were apparently related to turnover in the board of directors in the present study, which coincides with the findings of previous studies (Westphal \& Fredrickson, 2001; Aivazian, Ge, \& Qiu., 2005). The board of directors can play an important role in prompting better strategic adjustment of the firm, contributing diverse knowledge and expanding its absorptive capacity (Zahra \& Filatotchev, 2004). New managers are often appointed by boards of directors with a view to instigating change in firms. This suggests that the board of directors may be a decisive factor in strategic decision making (Zhang, 2010). Future research might therefore also examine the influence of the board on strategy formulation, to determine whether strategy is either a function of the board alone or a function of the board and management acting together (Castro et al., 2009).

Our study has contributed to the development of theory in this field, because it has highlighted that when a firm seeks a better strategic fit with the business environment, it might need to draw on the entire set of resources and capabilities within the TMT, including firm-specific skills; an implicit but as yet underdeveloped hypothesis in the literature (Bailey \& Helfat, 2003). As Miller (2003) indicated, firms can obtain competitive advantage from the resources and the skills that they already possess. Individual capabilities of reflection and reinterpretation can adapt personal behaviour to new situations and experiences (Tsoukas \& Chia, 2002), which favours strategic change. In addition, this work has highlighted the importance of human capital and its development when the TMT faces the experience of new roles. Rare and valuable resources are insufficient in themselves for the firm to adjust to the business environment. It is necessary to develop new ways of combining the actual set of resources and capabilities, to exploit new market opportunities and to neutralize threats (Newbert, 2008). The demographic composition of the TMT might be less important for change (Dalton, Daily, Ellstrand, \& Johnson, 1998) than the appointment of managers to posts that best suit their potential (Gordon et al., 2000; Bigley \& Wiersema, 2002; Greve \& Mitsuhashi, 2007; Brauer, 2009). Therefore, it is possible to match each person's behaviour and experience to the role that suits them best (Jarzabkowski, 2003) without changing the composition of the TMT.

This study has some limitations. Change is not usually caused by any one factor; even though there may be a dominant factor (such as the vision of the managerial team), most strategic change occurs for a number of significant reasons (Grouard \& Meston, 1995; Tsoukas \& Chia, 2002). As Langley (1999) pointed out, the synthetic strategy of qualitative analysis implies a sparser level of detail in process tracing for each case and has the advantage of producing relatively simple theoretical formulations. It contributes a generalization of the moderated data that only makes sense if dealing with a 
number of cases that should be over five. Although 10 firms were analysed in this study, in-depth case studies and empirical analyses should be undertaken with a view to verifying the relations that we have observed in this study.

\section{CONCLUSIONS}

Following the arguments of the resource- and capability-based theory, it has been shown that the managers as depositories of capabilities, knowledge and background can orient their decisions to initiate strategic change. However, is it necessary to incorporate new knowledge and capabilities in TMT to initiate strategic change? That is not so in our investigation, because the reorganization of roles between the members of the team renews the capabilities and the knowledge of top managers.

This study has affirmed that strategic change may be initiated by exploiting the actual set of resources and skills of the TMT, if these resources and knowledge are focussed on other management roles through its reorganization, which permits new ways of combining those resources and capabilities, to obtain a better adjustment to their business environment. So, it may be sufficient to initiate strategic change in stable business environments through the reorganization of the TMT to improve firm performance, without it being necessary to change the composition of the TMT. In second place, we contribute to knowledge in this field, because analysis of the content of the changes has enabled us to identify key modifications within the strategy and the structures that are always present when a strategic change takes place, which improves our knowledge of the theoretical construct of strategic change. Besides, identification of the sequence between top management change and strategic change may mean that we can accelerate the implementation of change in the present business environment, in which the speed of response is itself a competitive advantage.

The findings of this paper have numerous implications in this field.

First, this study clarifies the temporal sequence of TMT change and strategic change. In particular, the study demonstrates that TMT reorganization is a sufficient condition for strategic change. Practitioners need to know that strategic change can be achieved without having to dismiss members of the TMT. It may be more profitable to exploit the entire set of resources and capabilities, including firm-specific skills, within the TMT when strategic change is initiated. This situation underlines the importance of seeking the best fit between the knowledge and the experience of the TMT and the nature of their role in the firm.

Second, the analysis of strategic change indicates that the periods without change are scarce or inexistent, which supports the thesis that change is immanent in organizations (Tsoukas \& Chia, 2002). This work helps to distinguish the momentum of strategic change within that process of continual change. These findings enable the identification of the variables that bring about strategic change. The study has defined strategic change in a firm in terms of specific modifications of its strategy (growth or innovation) and structure (organization chart or subsidiary grouping criteria), which must be accompanied by changes in both its distribution of power in the firm and in its control systems. This, in turn, facilitates construction of relevant indicators to measure the level or degree of change that is achieved.

Third, CEO succession was not the main determining factor of strategic change, because subsequent TMT reorganization and TMT turnover were observed in most cases of CEO succession. The CEO might therefore need TMT collaboration to develop strategic change. In stable business environments, the reorganization of TMT without CEO succession appears be a better way of initiating strategic change to improve the performance of the firm. However, in turbulent environments, the combination of both CEO succession and reorganization initiates strategic change and may improve the performance of the firm. 


\section{ACKNOWLEDGEMENTS}

This research was supported by the Ministerio de Economía y Competitividad, Spain (ECO201345329-R). The authors are grateful to both the editor and the reviewers for their helpful comments and suggestions in preparing this paper for publication. This research has been financed by Spanish Ministry of Education (ECO2013-45329-R).

\section{References}

Adner, R., \& Helfat, C. E. (2003). Corporate effects and dynamic managerial capabilities. Strategic Management Journal, 24(10), 1011-1025.

Aivazian, V. A., Ge, Y., \& Qiu, J. (2005). Corporate governance and manager turnover: an unusual social experiment. Journal of Banking and Finance, 29(6), 1459-1481.

Amis, J., Slack, T., \& Hinings, C. R. (2004). The pace, sequence and linearity of radical change. Academy of Management Journal, 47, 15-39.

Bailey, E. E., \& Helfat, C. E. (2003). External management succession, human capital, and firm performance: an integrative analysis. Managerial and Decision Economics, 24(4), 347-369.

Balogun, J., \& Johnson, J. (2004). Organizational restructuring and middle manager sensemaking. Academy of Management Journal, 47, 523-549.

Barker, V. L., \& Duhaime, I. (1997). Strategic change in the turnaround process: theory and empirical evidence. Strategic Management Journal, 18, 3-38.

Barker, V. L. III, Patterson, P. W., \& Mueller, G. C. (2001). Organizational causes and strategic consequences of the extent of top management team replacement during turnaround attempts. Journal of Management Studies, 38(2), 235-269.

Beer, M., \& Nohria, N. (2000). Breaking the code of change. Boston, MA: Harvard Business School Press.

Bigley, G. A., \& Wiersema, M. F. (2002). New CEOs and corporate strategic refocusing: how experience as heir apparent influences the use of power. Administrative Science Quarterly, 47, 707-727.

Boeker, W. (1997). Executive migration and strategic change: the effect of top manager movement on productmarket entry. Administrative Science Quarterly, 42, 213-236.

Boyne, G. A., \& Meier, K. J. (2009). Environmental change, human resources and organizational turnaround. Journal of Management Studies, 45, 835-863.

Brauer, M. (2009). Corporate and divisional manager involvement in divestitures - a contingent analysis. British Journal of Management, 20, 341-362.

Brunninge, O., Nordqvist, M., \& Wiklund, J. (2007). Corporate governance and strategic change in SMEs: the effects of ownership, board composition and top management teams. Small Business Economics, 29(3), 295-308.

Castanias, R. P., \& Helfat, C. E. (1991). Managerial resources and rents. Journal of Management, 17(1), 155-171.

Castanias, R. P., \& Helfat, C. E. (2001). The managerial rents model: theory and empirical analysis. Journal of Management, 27(6), 661-678.

Castro, C., de la Concha, M., Gravel, J., \& Periñan, M. (2009). Does the team leverage the board's decisions? Corporate Governance: An International Review, 17, 744-761.

Churchill, G. A. (1999). Marketing research: methodological foundations (7th ed.). Orlando, FL: Dryden.

Clark, E., \& Soulsby, A. (2007). Understanding top management and organizational change through demographic and processual analysis. Journal of Management Studies, 44, 932-954.

Dalton, D. R., Daily, C., Ellstrand, A. E., \& Johnson, J. L. (1998). Meta-analytic reviews of board composition, leadership structure and financial performance. Strategic Management Journal, 19(3), 269-290.

Datta, D. K., Rajagopolan, N., \& Zhang, Y. (2003). New CEO openness to change and strategic persistence: the moderating role of industry characteristics. British Journal of Management, 14, 101-114.

Decker, C., \& Mellewigt, T. (2012). Business exit and strategic change: sticking to the knitting or striking a new path? British Journal of Management, 23, 165-178.

Durukan, B., Ozkan, S., \& Dalkilic, F. (2012). CEO turnover and corporate performance relationship in pre- and postIFRS period: evidence from Turkey. Journal of Business Economics and Management, 13, 421-442.

Dutton, J. E., \& Duncan, R. B. (1987). The creation of momentum for change through the process of strategic issue diagnosis. Strategic Management Journal, 8, 279-295. 
Eisenhardt, K. M. (1989). Making fast strategic decisions in high velocity environments. Academy of Management Journal, 32, 543-576.

Eisenhardt, K. M., \& Graebner, M. E. (2007). Theory building from cases: opportunities and challenges. Academy of Management Journal, 50, 21-32.

Farjoun, M. (2007). The end of strategy? Strategic Organization, 5, 197-210.

Fox-Wolfgramm, S. J. (1997). Towards developing a methodology for doing qualitative research: the dynamiccomparative case study method. Scandinavian Journal of Management, 13, 439-455.

Gedajlovic, E., Lubatkin, M. H., \& Schulze, W. S. (2004). Crossing the threshold from founder management to professional management: a governance perspective. Journal of Management Studies, 41(5), 899-912.

Geletkanycz, M. A., \& Hambrick, D. C. (1997). The external ties of top executives: implications for strategic choice and performance. Administrative Science Quarterly, 42, 654-681.

Gibbert, M., \& Ruigrok, W. (2010). The 'what' and 'how' of case study rigor: three strategies based on published research. Organizational Research Methods, 13, 710-737.

Gong, J. J., \& Wu, S. Y. (2011). CEO turnover in private equity sponsored leveraged buyouts. Corporate Governance: An International Review, 19(3), 195-209.

Gordon, S., Stewart, W. H. Jr., Sweo, R., \& Luker, W. A. (2000). Convergence versus strategic reorientation: the antecedents of fast paced organizational change. Journal of Management, 26(5), 911-945.

Greve, H., \& Mitsuhashi, H. (2007). Power and glory: concentrated power in top management teams. Organization Studies, 28, 1197-1221.

Grouard, B., \& Meston, F. (1995). Reingeniería del cambio. Diez claves para transformar la empresa. Barcelona: Marcombo.

Hambrick, D. C., Geletkanycz, M. A., \& Fredrickson, J. W. (1993). Top executive commitment to the status quo: some tests of its determinants. Strategic Management Journal, 14(6), 401-418.

Hambrick, D. C., \& Mason, P. A. (1984). Upper echelons: the organization as a reflection of its top managers. Academy of Management Review, 9, 193-206.

Harris, D., \& Helfat, C. (1997). Specificity of CEO human capital and compensation. Strategic Management Journal, 18(11), 895-920.

Hayward, M. L., \& Shimizu, K. (2006). De-commitment to losing strategic action: evidence from the divestiture of poorly performing acquisitions. Strategic Management Journal, 27(6), 541-557.

Jarzabkowski, P. (2003). Strategic practices: an activity theory perspective on continuity and change. The Journal of Management Studies, 40(1), 23-55.

Jarzabkowski, P. (2008). Shaping strategy as a structuration process. Academy of Management Journal, 51, 621-650.

Kesner, I. F., \& Dalton, D. R. (1994). Top management turnover and CEO succession: an investigation of the effects of turnover on performance. Journal of Management Studies, 31(5), 701-713.

Klarner, P., \& Raisch, S. (2013). Move to the beat: rhythms of change and firm performance. Academy of Management Journal, 56, 160-184.

Langley, A. (1999). Strategies for theorizing from process data. Academy of Management Review, 24, 691-710.

Langley, A., Smallman, C., Tsoukas, H., \& Van de Ven, A. H. (2013). Process studies of change in organization and management: unveiling temporality, activity, and flow. Academy of Management Journal, 56, 1-13.

Lant, T. K., Milliken, F. J., \& Batra, B. (1992). The role of managerial learning and interpretation in strategic persistence and reorientation: an empirical exploration. Strategic Management Journal, 13, 585-608.

Miller, D. (1993). Some organizational consequences of CEO succession. Academy of Management Journal, 36, 644-659.

Miller, D. (2003). An asymmetry-based view of advantage: towards an attainable sustainability. Strategic Management Journal, 24(10), 961-976.

Miller, D., \& Shamsie, J. (2001). Learning across the life cycle: experimentation and performance among the Hollywood studio heads. Strategic Management Journal, 22, 725-745.

Mosakowski, E. (1998). Managerial prescriptions under the resource-based view of strategy: the example of motivational techniques. Strategy Management Journal, 19, 1169-1182.

Newbert, S. L. (2008). Value, rareness, competitive advantage, and performance: a conceptual-level empirical investigation of the resource-based view of the firm. Strategic Management Journal, 29(7), 745-768.

Noda, T., \& Bower, J. (1996). Strategy making as iterated processes of resource location. Strategic Management Journal, 17, 159-192. 
Oster, S. (1990). Modern competitive analysis. New York: Oxford University Press.

Pentland, B. (1999). Building process theory with narrative: from description to explanation. Academy of Management Review, 24, 711-724.

Pettigrew, A. M. (1990). Longitudinal research on change: theory and practice. Organization Science, 1, 267-292.

Pettigrew, A. M. (1997). What is a processual analysis? Scandinavian Journal Management, 13, 337-348.

Pettigrew, A. M. Woodman, R., \& Cameron, K. (2001). Studying organizational change and development: challenges for future research. Academy of Management Journal, 44, 697-713.

Pfeffer, J. (1981). Power in organizations. Boston, MA: Pitman.

Pitcher, P., Chreim, S., \& Kisfalvi, V. (2000). CEO succession research: methodological bridges over troubled waters. Strategic Management Journal, 21, 625-648.

Poole, M. S., Van de Ven, A. H., Dooley, K., \& Holmes, M. E. (2000). Organizational change and innovation processes: theory and methods for research. New York: Oxford University Press.

Rajagopalan, N., \& Spreitzer, G. (1997). Toward a theory of strategic change: a multi-lens perspective and integrative framework. Academy of Management Review, 22, 48-79.

Rindova, V., Ferrier, W., \& Wiltbank, R. (2010). Value from gestalt: how sequences of competitive actions create advantage for firms in nascent markets. Strategic Management Journal, 31, 1474-1497.

Romanelli, E., \& Tushman, M. L. (1994). Organizational transformation as punctuated equilibrium: an empirical test. Academy of Management Journal, 37, 1141-1166.

Rosenbloom, R. S. (2000). Leadership, capabilities, and technological change: The transformation of NCR in the electronic era. Strategic Management Journal, 21(10-11), 1083-1103.

Sánchez, M. J., Galán, J. I., \& Suárez, I. (2006). Evolution of strategy and structure in large Spanish firm: a comparative European analysis. Universia Business Review - Tercer Trimestre, 11, 22-35.

Shen, W., \& Cannella, A. A. (2002). Revisiting the performance consequences of CEO succession: the impacts of successor type, post succession senior executive turnover, and departing CEO tenure. Academy of Management Journal, 45, 717-733.

Siggelkow, N. (2007). Persuasion with case studies. Academy of Management Journal, 50, 20-24.

Silverman, D. (2005). Doing qualitative research. London: Sage.

Simons, R. (1994). How new top managers use control systems as levers of strategic renewal. Strategic Management Journal, 15, 169-189.

Tsoukas, H., \& Chia, R. (2002). On organizational becoming: Rethinking organizational change. Organization Science, $13,567-582$.

Tushman, M. L., \& Romanelli, E. (1985). Organizational evolution: a metamorphosis model of convergence and reorientation. In L. L. Cummings, \& B. M. Staw (Eds.), Research in organizational behavior (Vol. 7, pp. 171-222). Greenwich, CT: JAI Press.

Tushman, M. L., \& Rosenkopf, L. (1996). Executive succession, strategic reorientation and performance growth: a longitudinal study in the U.S. cement industry. Management Science, 42, 939-953.

Van de Ven, A. (1992). Suggestions for studying strategy process: a research note. Strategic Management Journal, 13, 169-188.

Van de Ven, A., \& Huber, G. (1990). Longitudinal field research methods for studying processes of organizational change. Organization Science, 1, 213-219.

Van de Ven, A., \& Poole, M. (1995). Explaining development and change in organizations. Academy of Management Review, 20, 510-540.

Van de Ven, A., \& Poole, M. S. (2005). Alternative approaches for studying organizational change. Organization Studies, 26, 1377-1404.

Virany, B., Tushman, M. L., \& Romanelli, E. (1992). Executive succession and organization outcomes in turbulent environments: an organization learning approach. Organization Science, 3, 72-92.

Weisbach, M. S. (1988). Outside directors and CEO turnover. Journal of Financial Economics, 20, 431-460.

Westphal, J. D., \& Fredrickson, J. W. (2001). Who directs strategic change? Director experience, the selection of new CEOs, and change in corporate strategy. Strategic Management Journal, 22, 1113-1137.

Wiersema, M. F., \& Bantel, K. A. (1992). Top management team demography and corporate strategic change. Academy of Management Journal, 35, 91-121.

Wiersema, M. F., \& Bantel, K. A. (1993). Top management team turnover as an adaptation mechanism: the role of the environment. Strategic Management Journal, 14, 485-504.

Wind, J. Y., \& Main, J. (1999). Driving change: how the best companies are preparing for the 21st century. London: Kogan Page. 
Yin, R. (1993). Case study research, design and methods (2nd ed.). Beverly Hills, CA: Sage.

Zahra, S. A., \& Filatotchev, I. (2004). Governance of the entrepreneurial threshold firm: a knowledge-based perspective. Journal of Management Studies, 41(5), 885-897.

Zhang, P. (2010). Board information and strategic tasks performance. Corporate Governance: An International Review, $18,473-487$.

Zhang, Y. (2006). The presence of a separate COO/president and its impact on strategic change and CEO dismissal. Strategic Management Journal, 27, 283-300.

Zhang, Y., \& Rajagopalan, N. (2010). Once an outsider, always an outsider? CEO origin, strategic change, and firm performance. Strategic Management Journal, 18, 334-346.

\section{APPENDIX 1: MEASURING ORGANIZATIONAL CHANGE: DEFINITION OF VARIABLES}

\section{Changes in Strategy}

Low price: change in the company's price strategy, which means a significant drop in prices to leave the company in a more attractive position compared with its competitors. It should be distinguished from forced price change resulting from environmental changes affecting all companies in the sector, for example, a drop in fuel prices as a result of a reduction in the price of a barrel of crude oil.

Product quality: change in the firm's product quality strategy, which means actions the company takes and specifically designs for this type of effect, such as positive modifications and improvements to the end product. It includes quality assurance certificates obtained by the company as indicators of the changes it has made in this respect.

Customer assistance quality: change in the company's customer assistance strategy and covers specific measures taken in this regard, for example, an improvement in personal customer assistance or customer welcoming protocols at the plant.

Delivery lead-times: change instigated by the company in its delivery lead-time strategy.

Degree of reaction to customer requirements: change in the company's degree of reaction to customer requirements, that is, the company is continuously geared and prepared to modify its products and its service provision, in order to adapt itself to new market requirements and customer tastes and preferences.

Innovation: change in innovation within the company. Innovation is understood to refer to adopting new products, services or processes - new in that they have never been implemented in the company before - whether in-sourced or outsourced, generally with the aim of improving performance and efficiency, including significant changes in the R\&D budget.

Product exclusivity: change in the exclusive nature of the product that the company puts on the market; clearly a step towards a differentiation strategy.

Growth: change in the strategic size of the company. The most common means of achieving this are mergers, takeovers and strategic alliances. In this regard, a distinction should be made between what is known as short-term alliances (joint ventures) and structural alliances. The former refers to agreements, normally short or fixed term, with other companies, designed to jointly cover some specific plan of action on the market. The second type is characterized by being permanent, which affects the core competitive essence of both firms; not to be confused with high-turnover operations, which form part of the company's ordinary operations. 
Sales turnover: change in the company's sales turnover strategy. This specifically covers all actions aimed at entering new markets in which the company, until now, has not been present.

Market share: change in the company's strategy regarding the achievement of a larger share of its current markets. Unlike the previous variable, the aim now is to achieve a stronger position and participation in markets where the company already operates.

Advertising and publicity: change in the strategy related to significant components of communications. Among other items, it encompasses changes in advertising and public relations variables (image and sponsorship).

Distribution: change in the distribution strategy for the company's products and services. Distribution is understood to mean a series of tasks and operations that take place from the point at which the product goes into the storage warehouse until its delivery to the customer. It includes changes to wholesalers and the supply chain.

Breadth of product range: change in the company's product range. It is important to distinguish between the concepts of product line and product range. Line refers to a set of products with common characteristics, whereas product range refers to the number of different lines the company sells; thus the number of product lines determines the breadth of the product range.

\section{Changes in Structure}

Organization chart: change in the firm's organization chart, which depicts a summary of its hierarchical structure, mainly reflecting the positions and relationships of authority among the different items on the chart, formal communication channels, formal structuring (divisions, departments, sections) and a diagram of the formal distribution of responsibilities.

Grouping criteria: change in the grouping criteria adopted by companies to determine the design of their organizational structure or business units. Grouping by function is aimed at putting those job positions that perform similar content-related tasks in the same department, so that departments will then correspond to different functions - marketing, production, finance and so on. Grouping by markets is aimed at structuring job positions on the basis of the product for which they are working, that is, the organization is divided into sections equivalent to market segments for the different products and services sold by the company. Finally a matrix structure indicates when groupings by function or by market are set up under the same chain of command so that subordinate job positions are covered by dual supervision.

Business unit size: change in the absolute and relative size of the different business units in a diversified company, also known as its 'organization portfolio'. Examples of these include taking a larger shareholding in a subsidiary by the holding company (see Note 2), or the acquisition, disposal, investment in or disinvestment in a fringe business line. It includes setting up new business lines and includes increases or reductions to overall headcount.

Reorganization of business units: change to the mix of business lines operated by the company. Examples include the creation of central management offices for subsidiary companies or the horizontal integration of different related parts into one larger business.

Structurally autonomous plants and other divisions: structural change in structurally autonomous plants and other divisions - such as opening, expanding or closing them. (To distinguish the difference between actions relating to the holding company and its subsidiaries, see Note 2 below.) 


\section{Changes in Power Distribution}

Share capital structure: change in the company's share capital structure, which means a modification in percentage holdings as a result of buying or selling shares. Special mention should be made of equitybased share capital extensions, which, given the nature of these operations, should not be considered as changes in power distribution because they do not represent modifications of shareholding percentages. Neither should reductions in share capital represent changes. Extensions can be considered as such only when they cause significant changes in shareholding percentage. Split operations (modification of share face value) are not considered changes in power distribution. Announcements of share capital extensions should not be computed as changes until they become effective.

\section{Changes in Control Systems}

Administrative procedures: change in the company's administrative procedures, which is understood to mean a series of interrelated steps that need to be taken sequentially to perform different administrative tasks. An example is a change of procedures carried out in the procurement of raw materials. Changes to the incentive system are also covered under this heading.

Budgets: changes to budgeting, which is the written numeric expression of the business plan, that is, the allocation of resources to the different business lines in the company. Budgets reflect where resources are to be used and how the company is to be managed, while also serving as a means for establishing priorities.

Information systems: change in the company's information systems, especially its accounting system, which is the fundamental basis for decision taking.

Stock control: change in the stock control systems and warehouse management (inventory storage and maintenance, product turnover and so on).

Planning systems: change in the planning systems, which means modifications to the target setting systems (how they are established), decision-taking criteria, policies or regulations on what the company should or should not do.

Difference $\geq 1 \%$ in Selling General Administrative expenses (SGA) costs/sales: change in the ratio between general and administrative expenses compared with sales, a result which would be evidence of a change in the firm's control systems.

\section{Notes}

1. It should be remembered that the objective is to measure change, so that only those items of news that correspond to modifications in the company's life as per the different sections described above should be recorded.

2. A company may be considered a subsidiary of another company when a significant percentage of its share capital belongs to the latter. Generally, changes in the subsidiary will be covered as business units under the option for the structure variable. However, when a holding company owns the majority of the shares in a subsidiary and it is a unique business (the business of the subsidiary coincides with the holding company's main business line or one of its main activities), then changes in the subsidiary should be recorded as changes in the main holding company under the relevant category corresponding to the nature of such change.

3. It is possible that one item of news represents changes in different variables at the same time. In such cases, the modifications shall be recorded for all those variables affected in any one of the relevant categories. However, it should be remembered that such cases are exceptional and not the norm. 
N APPENDIX 2: MEASURING ORGANIZATIONAL CHANGE

Changes in Strategy

\begin{tabular}{|c|c|c|c|c|c|c|c|c|c|c|c|c|}
\hline $\begin{array}{l}\text { Low Price } \\
\text { Modifications }\end{array}$ & $\begin{array}{l}\text { Product } \\
\text { Quality }\end{array}$ & Customer & & $\begin{array}{l}\text { Degree of } \\
\text { Reaction to }\end{array}$ & $\begin{array}{c}\text { Innovations } \\
\text { Product }\end{array}$ & & $\begin{array}{c}\text { Growth } \\
\text { Mergers } \\
\text { Strategic Alliances }\end{array}$ & \multirow{2}{*}{$\begin{array}{c}\text { Sales } \\
\text { Turnover }\end{array}$} & \multirow{2}{*}{$\begin{array}{l}\text { Market } \\
\text { Share }\end{array}$} & \multirow[b]{2}{*}{ Advertising } & \multirow[b]{2}{*}{ Distribution } & \multirow{2}{*}{$\begin{array}{c}\text { Width of } \\
\text { Product } \\
\text { Range }\end{array}$} \\
\hline $\begin{array}{l}\text { Compared } \\
\text { competitors }\end{array}$ & $\begin{array}{l}\text { Improvement } \\
\text { Modification }\end{array}$ & $\begin{array}{c}\text { Assistance } \\
\text { Quality }\end{array}$ & $\begin{array}{l}\text { Lead- } \\
\text { Times }\end{array}$ & $\begin{array}{c}\text { Customer } \\
\text { Requirements }\end{array}$ & $\begin{array}{l}\text { Services } \\
\text { Process }\end{array}$ & $\begin{array}{c}\text { Product } \\
\text { Exclusivity }\end{array}$ & $\overline{\text { Short time Structural }}$ & & & & & \\
\hline
\end{tabular}

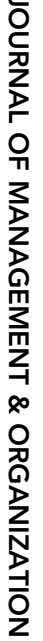

Changes in Structure

Organization Chart Relationships of authority Communications channels Responsibilities

Grouping Criteria Function, Markets, Matrix

Business Unit Size

Reorganization of Business Units
Structurally Autonomous Plants and Other Divisions Opening or closing 


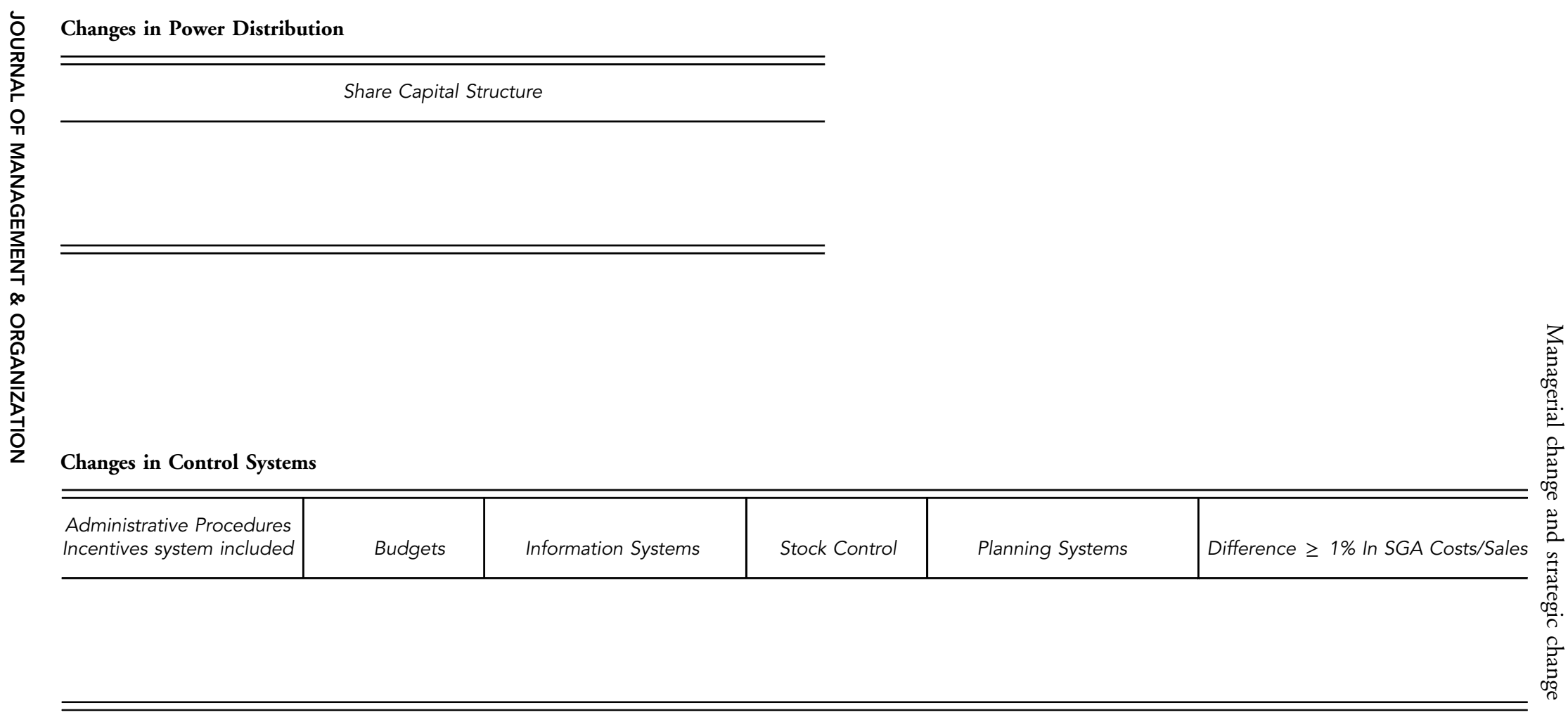

